\title{
Da comunicação à educação: a importância dos estudos de recepção ${ }^{1}$
}

Maria Aparecida Baccega

Coordenadora adjunta do Programa de Mestrado Comunicação e Práticas de Consumo, da Escola Superior de Propaganda e Marketing de São Paulo. Professora Livre-Docente aposentada do Departamento de Comunicaçoes e Artes da ECA-USP.

E-mail: mabga@usp.br

Margaret de Oliveira Guimarães

Diretora Pedagógica da Escola de Educação Infantil e

Ensino Fundamental Albert Sabin, em Ribeirão Preto.

E-mail: guimapitta@hotmail.com

As pesquisas sistemáticas de comunicação iniciaram-se na década de 1920, nos Estados Unidos, e têm desde então se desenvolvido celeremente, tendo em vista a complexidade e a importância do fenômeno. O pólo da emissão foi largamente privilegiado na maior parte desse trajeto.

A concepção segundo a qual o receptor era um vaso onde se despejavam regras, que redundavam em comportamento adequado às mensagens emitidas, vigorou durante décadas.

Sobretudo a partir dos anos 1970, no entanto, a recepção começa a ser concebida como ativa, admitindo-se a participação dos sujeitos na reconstrução dos significados das mensagens. Se antes os estudos e pesquisas de comunicação já interessavam à escola, na atualidade essa nova perspectiva abriu caminhos importantes para os que trabalham com educação.

Que pretende o professor senão comunicar-se? E de que modo ele concebe o aluno: como um receptor passivo, vaso onde se depositam regras que lhe serão cobradas como únicas possíveis, ou como um receptor ativo, que é capaz de reelaborar, de ser co-autor dos significados das mensagens?

A opção por uma dessas duas concepções estrutura caminhos díspares para o processo educacional. No caso da primeira - o receptor passivo -, temos a educação autoritária que ainda vige em grande parte das escolas; no caso da segunda - o receptor ativo -, há o processo educacional permeado pelo diálogo, pelo construir juntos de professores e alunos, o que resulta numa educação democrática, aberta, e que possibilita ao aluno reconstruir o mundo em que vive.

1. Crítica do livro de Ana Carolina Escosteguy e Nilda Jacks, Comunicação e recepção, São Paulo: Hacker Editores, 2005, $128 \mathrm{p}$. 
comunicação \& educação • Ano XI • Número 3 • set/dez 2006

Quando falamos em comunicação, não estamos tratando apenas daquela veiculada pelos suportes tecnológicos (chamados meios de comunicação, mídia), embora os consideremos de extrema importância na atualidade, configurandose, inclusive, como destacados editores de realidades. Comunicação é interação entre sujeitos que, para tanto, podem utilizar-se predominantemente - e às vezes tão-somente - do mais democrático de todos os suportes: o aparelho fonador. As feiras, a literatura de cordel, o circo, o teatro, o folhetim, o carnaval, entre muitas outros, configuram-se como comunicação e constituem as matrizes históricas dos produtos dos meios de comunicação, tal qual os conhecemos hoje.

Para que haja comunicação, é preciso que os interlocutores tenham uma memória comum, participem de uma mesma cultura, pois são as referências que vão traçando percursos de leitura. Por isso dizemos que a comunicação está imersa na cultura. É uma prática cultural que produz significados, ou seja, a partir do que está e já é naquela cultura, ressemantizam-se os significados em cada ato de comunicação. Implica sempre emissão e recepção, resultando na construção de sentidos novos, renovados - ou sentidos reconfigurados -, produzidos nesse encontro. Cada produto, cada programa dos meios de comunicação, será produzido e interpretado, entendido a partir dessa memória comum, dessas referências culturais.

O receptor-sujeito vai ressignificar o que ouve, vê ou lê, apropriar-se daquilo a partir de sua cultura, do universo de sua classe, para incorporar ou não a suas práticas.

Hoje se sabe que os receptores se tornam co-produtores do produto cultural. São eles que o (re)vestem de significado, possibilitando a atualização de leituras, o rompimento de caminhos preestabelecidos de significados, a abertura de trilhas que poderão desaguar em reformulações culturais.

A recepção, como ato cultural, desempenha importante papel na construção da realidade social. Daí a importância de seu estudo. Através desses estudos podemos descobrir quais são os processos reais que resultam do encontro dos discursos dos meios de comunicação apropriados (transitoriamente) ou incorporados (com permanência na cultura) pelos sujeitos-receptores imersos em suas práticas culturais.

Os estudos de recepção estão preocupados com as características socioculturais dos receptores. Desse modo, o foco se desloca para as práticas sociais e culturais mais amplas, nas quais eles estão integrados. É nesse espaço que se estudará a ressignificação que os receptores produzem com relação aos produtos dos meios de comunicação, ao entendimento das mensagens. É nesse espaço que ocorre o processo educacional.

\section{EXPLORANDO A ROTA DOS ESTUDOS DE COMUNICAÇÃO/RECEPÇÃO}

Buscando conhecer quem é, qual o lugar e qual a ação do sujeito-receptor no processo comunicacional, surge o trabalho de Nilda Jacks e Ana Carolina 
Escosteguy (Comunicação e recepção, São Paulo, Hacker Editores, 2005, 128 p.), que oferece a pesquisadores da área, a educadores e a todos aqueles que se interessam pelo tema uma reconstrução histórica do espaço conceitual e metodológico da recepção, a partir de um mapeamento teórico capaz de organizar, respeitando uma ordem cronológica, os paradigmas que nortearam os estudos da comunicação que marcaram o século XX.

As autoras abrem a reflexão sobre o tema sugerindo, logo na introdução do trabalho, a superposição dos dois campos de estudo que nomeiam o trabalho: a comunicação e a recepção. Para Jacks e Escosteguy, pensar a comunicação e a recepção é estabelecer uma relação de dois diferentes fenômenos que compõem um mesmo processo, já que a recepção é parte intrínseca da comunicação.

Ainda que se considere essa relação indissociável, as pesquisadoras se dispõem a discutir outro problema teórico: a adequação do termo recepção para nomear as relações que os indivíduos mantêm com os meios de comunicação, sobretudo no âmbito das pesquisas desenvolvidas nos meios acadêmicos que ainda conservam mo-

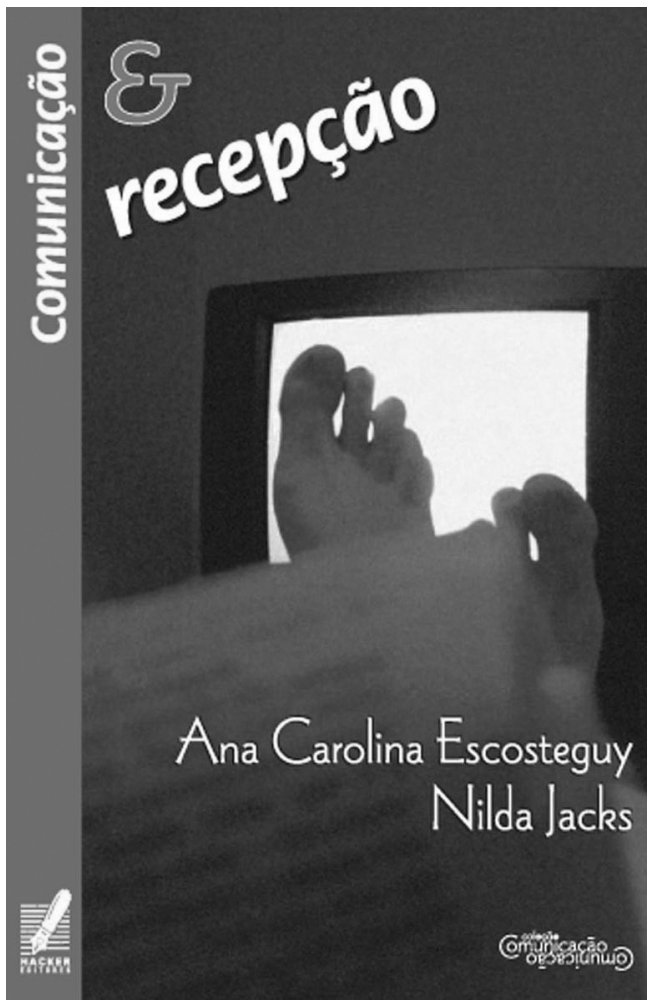
delos teóricos para os quais os consumidores das mensagens mediáticas são receptáculos passivos.

Nesse sentido é que o corpo de todo o trabalho de Jacks e Escosteguy compõe uma estrutura na qual se apresenta um mapeamento de perspectivas teóricas e metodológicas que possibilita a compreensão das formas como as pesquisas em comunicação nasceram e evoluíram.

Abrindo o primeiro capítulo, o texto apresenta, de forma criteriosa e abrangente, a classificação teórica adotada pela tradição internacional, a partir das contribuições de Jensen e Rosengren ${ }^{2}$, a qual teve forte divulgação no contexto latino-americano. Nessa classificação, inclui-se a teoria dos efeitos - geradora das primeiras pesquisas em comunicação, na década de 1920: cenário em que a maior preocupação era a propaganda política, a opinião pública e as campanhas publicitárias. Ao lado desse postulado teórico, discute-se outra perspectiva, a dos usos e gratificações, segundo a qual os membros da audiência eram conscientes de necessidades relacionadas aos meios de comunicação; pressupunha-se, a partir de então, a existência de uma audiência ativa. Tal questão é bem esclarecida pelas autoras adiante, à página 56 do referido livro.
2. JENSEN, K. B.; ROSENGREN, E. Five traditions in search of the audience (Cinco tradições em busca de uma audiência). European Journal of Communication, v. 5, 1990. 
Ainda nesse primeiro capítulo, Jacks e Escosteguy apresentam a corrente dos estudos literários - um olhar sobre a audiência inscrita no texto -, em que se encontra a estética da recepção. Jauss, Iser e Gumbrecht são os estudiosos que se destacam.

Jauss tem entre suas principais teses

[...] a de que o fato primordial da história da literatura é a relação dialógica entre leitor e obra, ou seja, o leitor de cada época é quem atualiza a historicidade da obra, a qual de certa maneira predetermina a recepção, oferecendo orientações a seu destinatário, porque ela evoca "o horizonte de expectativas" e as regras do jogo familiares ao leitor. Cada leitor pode reagir individualmente a um texto, mas a recepção é um fato social, uma medida comum localizada entre essas reações particulares; portanto, nessa perspectiva, a inclusão do contexto passa a ser central ${ }^{3}$.

Também para os estudos culturais, campo de cruzamento de diversas disciplinas que permitiram a combinação da pesquisa textual com a social, a pesquisa de comunicação não deve se restringir aos meios, mas buscar as relações entre textos, grupos sociais e contexto, ou seja, "entre práticas simbólicas e estruturas de poder" aos usos dos meios e à posição social ocupada pelos leitores.

Nesse contexto, apontam as autoras, era possível assistir a dois movimentos relevantes na evolução das pesquisas de campo: por um lado, a comunicação de massa passa a ser vista como parte integrante das demais práticas da vida diária; por outro, dá-se ênfase maior à posição ocupada pelos receptores. Surgem, assim, as primeiras perspectivas dos estudos de recepção com os contornos que conhecemos hoje.

No capítulo 2, Jacks e Escosteguy esboçam as configurações das produções teóricas da América Latina que se voltavam para sua própria realidade. A partir dos anos 1980, no cenário latino-americano, enfatizam as autoras, as pesquisas em comunicação começam a revelar sinais de mudança, explicados tanto pelas reflexões pertinentes ao próprio campo da comunicação como às ciências sociais em geral. Há de se acrescentar a isso que a proposta da recepção ativa encontra seu desenho na concepção do receptor como produtor de sentido. Ou seja: ele é também autor da obra.

Ao conceber os usos dos meios como inalienáveis da situação sociocultural dos receptores que "reelaboram, ressignificam e ressemantizam os conteúdos massivos" , Jacks e Escosteguy retomam o debate de Martín-Barbero responsável pela difusão do conceito de mediação: outra abordagem do processo comunicativo.

Sobreleva-se a dobradinha Martín-Barbero \& García Canclini, além de Oro-

3. ESCOSTEGUY e JACKS

op. cit., p. 36.

4. Ibid., p. 39.

5. Ibid., p. 66.

6. Ibid., p. 56 . zco Gómez, cujas contribuições são bastante elucidadas pelas autoras, incluindo a distinção entre estudos dos efeitos e estudos de recepção ${ }^{6}$.

Dizem as autoras:

No entanto, para a pesquisa latino-americana chegar a essa posição de destaque, Guillermo Orozco avalia que ela passou por "um parto longo e difícil. Longo porque foram necessários vários anos para desvincular-se da racionalidade própria 
dos estudos dos efeitos [...]". Difícil, porque os estudos de recepção tiveram que construir uma legitimidade científica a "ferro e fogo" e sobreviver em um "campo minado" por outras correntes de pensamento ${ }^{7}$.

O capítulo subdivide-se em Consumo cultural, destacando a contribuição de García Canclini; Frentes culturais, que trata da colaboração de Jorge Gonzalez; Recepção ativa, retomando as propostas do CENECA (Centro de Indagación y Expressión Cultural y Artística, do Chile), liderado por Valério Fuenzalida e Maria Elena Hermosilla, entre outros; Uso social dos meios,

[...] uma concepção de Martín-Barbero para entender a relação entre receptores e meios, que parte dos estudos das articulações entre as práticas de comunicação e os movimentos sociais, observando as diferentes temporalidades e as pluralidades de matrizes culturais, constituindo-se, portanto, num possível desenvolvimento de sua formulação maior, a perspectiva das mediações ${ }^{8}$,

trazendo à boca de cena o livro Dos meios às mediações ${ }^{9}$, de Jesús Martín-Barbero, sem dúvida um marco nas pesquisas de comunicação em todo o mundo.

Modelo das multimediações é outra subdivisão do capítulo 2. Aí se destaca, sobretudo, Guillermo Orozco Gómez, sendo também avaliadas as contribuições de Maria Immacolata Vassalo de Lopes e de Guillermo Sunkel; e, finalmente, a última subdivisão - Outras contribuições -, que as autoras reservaram para os vários aportes da América Latina, entre os quais Rosário Sanchez Vilela, Maria Teresa Quiróz, Florência Saintout, Beatriz Sarlo, Maria Cristina da Mata, Alejandro Grimson, Marta Vilela.

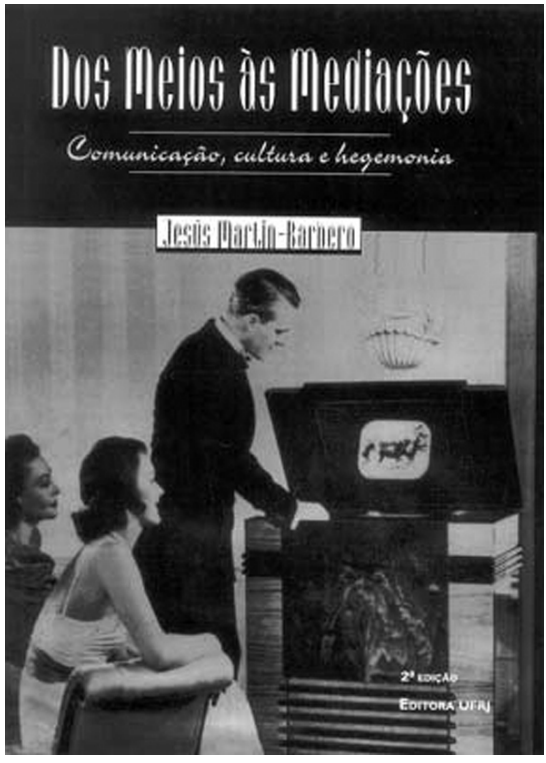

A trajetória brasileira, que ocupa as reflexões apresentadas no terceiro capítulo, é marcada pelo interesse voltado para o sujeito-receptor e fecha o debate apresentado, reiterando a idéia de que a importância da cultura deriva do fato de que ela constitui a estrutura e a história. Assim, de acordo com as autoras, "não se escolhe entre o fator econômico ou o ideológico, mas se deve construir uma proposta dialética e flexível de análise das práticas culturais"10.

Nessa concepção dialética é que entendemos poder encontrar as respostas aos questionamentos iniciais, buscando a recepção como lugar do sujeito da sociedade global.

São apresentadas as várias contribuições de pesquisadores brasileiros, entre os quais Maria Immacolata Vassalo de Lopes, Mauro Wilton de Sousa, Eclea Bosi, Ondina Fachel, Elza Dias Pacheco, Rosa Maria Bueno Fischer, em variados momentos. Além das próprias autoras do livro, que se têm destacado pela contribuição oferecida a esses estudos.
7. OROZCO GÓMEZ Guillermo. Recepción y mediaciones. Casos de investigación en comunicación en América Latina (Recepção e mediação. Casos de investigação em comunicação na América Latina). Buenos Aires: Norma, 2002. p. 15. Citado em ESCOSTEGUY \& JACKS, op. cit., p. 56.

8. ESCOSTEGUY e JACKS op. cit., p. 65.

9. MARTÍN-BARBERO, Jesús. Dos meios às mediações: comunicação, cultura e hegemonia. 2. ed. Rio de Janeiro: UFRJ, 2003. $369 \mathrm{p}$.

10. ESCOSTEGUY e JACKS, op. cit., p. 94. 
Ao final do capítulo 3, afirmam as autoras:

Retomando os ensinamentos de Martín-Barbero, estudar a recepção implica o questionamento do modelo comportamental que centraliza a ação no emissor; dessa forma, pesquisá-la é posicionar-se num lugar a partir do qual se deve repensar o processo inteiro da comunicação, inclusive repercutindo na reflexão de uma epistemologia da comunicação ${ }^{11}$.

Comunicação e recepção é leitura obrigatória àqueles que se aventuram a alinhavar os contornos da cultura contemporânea e dos processos identitários dos cidadãos do mundo global que, como sabemos, têm na comunicação um dos mais importantes pilares de sustentação. Também, para todos os que trabalhamos com educação, pois possibilita-nos conhecer melhor o caminho que nos leva a perceber que o conteúdo de nossas aulas só significa no território que se forma no encontro com o universo cultural do aluno. E que ele é, sobretudo, um sujeito-receptor, bastante ativo.

Resumo: $\mathrm{O}$ artigo analisa o livro de Nilda Jacks e Ana Carolina Escosteguy - Comunicação e recepção - que, buscando conhecer quem é, qual o lugar e qual a ação do sujeito-receptor no processo comunicacional, oferecem a pesquisadores da área, a educadores e a todos aqueles que se interessam pelo tema uma reconstrução histórica do espaço conceitual e metodológico da recepção, a partir de um mapeamento teórico capaz de organizar, respeitando uma ordem cronológica, os paradigmas que nortearam os estudos da comunicação que marcaram o século XX. São apresentadas também as várias contribuições de pesquisadores brasileiros, entre os quais Maria Immacolata Vassalo de Lopes, Mauro Wilton de Sousa, Eclea Bosi, Ondina Fachel, Elza Dias Pacheco, Rosa Maria Bueno Fischer, em variados momentos.

Palavras-chave: crítica, mediações, estudos de recepção, comunicação de massa, educação.
Abstract: The article analyses the book written by Nilda Jacks and Ana Carolina Escosteguy - Comunicação e recepção (Communications and reception). In search for the identity, the place and action of the receptor subject in the communication process, Jacks and Escosteguy offer to researchers, educators and to all people interested on this issue a historical reconstruction of the conceptual and methodological spaces of reception. From a theoretical analysis, always respecting chronological order, they organize the paradigms that guided main communication studies in the XXth century. Several contributions of Brazilian researchers - Maria Immacolata Vassalo de Lopes, Mauro Wilton de Sousa, Eclea Bosi, Ondina Fachel, Elza Dias Pacheco, Rosa Maria Bueno Fischer -, are also presented in various moments.

Keywords: criticism, mediations, media reception studies, mass communication, education. 